\title{
Guidelines for the Management of Community Enterprises in the Songkhla Lake Basin of Thailand
}

\author{
Thongphon Promsaka Na Sakolnakorn ${ }^{1} \&$ Aree Naipinit $^{2}$ \\ ${ }^{1}$ Faculty of Liberal Arts, Prince of Songkla University, Hat Yai Campus, Songkhla, Thailand \\ ${ }^{2}$ Faculty of Management Science, Khon Kaen University, Khon Kaen, Thailand \\ Correspondence: Thongphon Promsaka Na Sakolnakorn, Faculty of Liberal Arts, Prince of Songkla University, \\ Hat Yai, Songkhla 90112, Thailand. E-mail: thongphon.p@psu.ac.th
}

\author{
Received: May 7, 2013 Accepted: June 12, 2013 Online Published: August 30, 2013 \\ doi:10.5539/ass.v9n11p166 URL: http://dx.doi.org/10.5539/ass.v9n11p166
}

\begin{abstract}
The objectives of this study were 1) to identify problems and threats to the management of community enterprises in the Songkhla Lake basin; and 2) to study guidelines for the management of community enterprises in the Songkhla Lake basin. The researchers conducted a fieldwork survey and in-depth interviews with 30 entrepreneurs using convenience sampling and snowball sampling. In addition, the researchers used the focus group technique by inviting nine experts to discuss the guidelines for the management of community enterprises. From this study, we found that the main problems are marketing, finances and accounting, production, management information systems, product design, and the cost of production. We found that the state agency is an important unit in the development and support of community enterprises with respect to knowledge, all aspects of production and management skills, marketing support, and specifying the regulations for community enterprises.
\end{abstract}

Keywords: guidelines, management, community enterprises, songkhla lake basin

\section{Introduction}

Community enterprises are enterprises in which members of a community are involved, such that these members participate in the organization through production, selling products, sharing money to set up enterprises, financial management, and using resources in the community for production (Petprasert \& Wongkul, 2002, p. 1-11). In addition, community enterprises work for sustainable regeneration in their communities through a mix of environmental, economic, cultural, and social activities (Development Trusts Association, 2000, p. 3). The community sector is made up of thousands of charities, social enterprises, faith groups, and unconstituted community groups in metropolitan, urban, and rural community areas (Bailey, 2012). However, Pongpit (2005, p. 40) explained seven characteristics of community enterprises, as follows: ownership by a group of people in the community; finished goods provided through a production process in the community; goods and production that come from community's creative work and innovations; goods and products based on local wisdom, but combined with universal wisdom; local people working together using participation and all activities are related through a network system, knowledge practice, and self-sufficiency of the family and community.

Community enterprises make up a sector that boosts the economy in rural areas. Most of these enterprises are small and medium-sized. However, Promsaka Na Sakolnakorn (2009) found six factors that negatively affected textile industry development: 1) knowledge and personnel, 2) recognition of value added, 3) supply chain, 4) marketing management, 5) manufacturing management and technology, and 6) financial management. Purateera et al. (2009) studied the factors that affect small enterprise management in northeastern Thailand. The results showed that the factors that affected management consisted of: 1) knowledge and skills of the entrepreneur, 2) the entrepreneur's capability, 3) technology, 4) the entrepreneur's attitude, 5) the motivation for engaging in business, 6) the source of investment funds, and 7) the entrepreneur's creativity. In addition, Lee and Hsin (2004) suggested that human development will raise the skills and knowledge of humans. On the other hand, Suantan et al. (2008) studied a community village closely in the Songkhla Lake basin and found that the villagers had a great deal of knowledge; however, they lacked knowledge management and knowledge sharing skills, and knowledge was not transferred to other people, which prevented the community from developing. 
The Songkhla Lake basin is located in southern Thailand, within the three provinces of Phattalung, Songkhla, and Nakorn Si Thammarat. The Songkhla Lake basin covers approximately 7,687 sq.km. of land area and approximately $1,042 \mathrm{sq} . \mathrm{km}$. of lake area, for a total area of approximately $8,729 \mathrm{sq} . \mathrm{km}$ (Ratanachai \& Sutiwipakorn, 2006). There are more than a thousand community enterprises in the Songkhla Lake basin area. Runglertkrengkrai et al. (1999) studied small and medium enterprises in Songkhla Province, in the south of Thailand, and they found that many entrepreneurs would like to gain more knowledge about marketing management, production, accounting, financial management, and general management. According to Promsaka Na Sakolnakorn and Sungkharat (2013), in recent years, many community enterprises have stopped working, and they face many problems related to growth, such as marketing management, sales promotion, production management, and more. As we mentioned, community enterprises should strive to grow, but there is a lack of research on community enterprises in the Songkhla Lake basin. Thus, for this paper, the research question is: What are the problems and threats to management of community enterprises in the Songkhla Lake basin, and what are the guidelines for management of community enterprises in the Songkhla Lake basin?

\section{Objectives}

1) To identify problems and threats to the management of community enterprises in the Songkhla Lake basin.

2) To study guidelines for the management of community enterprises in the Songkhla Lake basin.

\section{Methodology}

In this study, we use a qualitative approach and focus on community enterprises that are registered with the Department of Agricultural Promotion Office, Ministry of Agriculture and Cooperatives. We conducted in-depth interviews of 30 to 60 minutes with 30 entrepreneurs in the Songkhla Lake basin between March 2011 and November 2012. We selected the sample by convenience sampling and snowball sampling. To analyze the data, we conducted content analysis.

In addition, the researchers used the focus group technique by inviting nine people (experts, entrepreneurs, and government employees) to discuss the development of guidelines for the management of community enterprises. Finally, the researchers analyzed the data by conducting content analysis and descriptive analysis.

\section{Literature Review}

Promsaka Na Sakolnakorn (2011) suggested that many entrepreneurs in northeastern Thailand faced the problem of how to manage their work, given that most employees in northeastern Thailand work on their own farms in addition to having a factory job. This is especially difficult for business owners during the agriculture season, when employees stop coming to work so they can tend to and harvest their crops. In addition, the local labor force usually consists of older people, given that middle-aged people and teenagers are moving to the bigger cities to seek work. In addition, Promsaka Na Sakolnakorn et al. (2010) suggested that the local culture and skills of workers in the northeastern region are obstacles to entrepreneurship. Kongmanila and Takahashi (2009) suggested that, in Laos, skilled labor is an important factor for entrepreneurship.

Adonisi and Wyk (2012) studied entrepreneurs in South Africa and found eight factors that affected marketing management: decision making, motivation system, management support, innovation, financial support, flexible working hours, organization of work, and time of work. In addition, Basco and Rodriguez (2011) explained that the important factors affecting family business performance are strategic process, human resources, succession, and the board of directors, so that family firms can achieve business success using a combination of family and business orientations in their decision making. Providing high-quality service can improve a bad image for entrepreneurs (Yim et al., 2007), and good service can drive word-of-mouth recommendations from customer to customer and increase customer satisfaction (Netemeyer \& Maxham, 2007).

Seyoum (2007) stated that using information technology, such as sharing information between entrepreneurs, suppliers, and consumers through the Internet, will create cooperation in product development, production cooperation, production planning, and other factors. Swenson (2004) explained that new production requires substantial investments, which small enterprises are rarely able to undertake. Thus, they will look for new business partners to produce goods for them or reduce their cost of investment. In addition, Gorman, Rosa, and Faseruk (2005) suggested that a knowledge base is important for enterprises; for example, some large enterprises have created training centers to train their employees. Organizations that manage knowledge can evaluate core processes, capture insights about what they find, combine their skills and experiences, innovate, and apply new ideas quickly (Promsaka Na Sakolnakorn, 2011).

Community enterprises in Songkhla Lake basin face many problems. For example, Saengthong (2010) suggested that community enterprises in Koryor sub-district are at a disadvantage with regard to valuable labeling of 
products and lack of trademarks; label and packaging designs are not attractive to customers, so community enterprises should develop their capability for more attractive packaging designs, to drive customer satisfaction. Nambure (2012) stated that many community enterprises in lower-south Thailand do not do accounting, as they lack the knowledge and skills needed to implement accounting report systems. In addition, Jariyapong et al. (2010) suggested that local wisdom in the community around Songkhla Lake basin has been lost because local people's lives have been subject to globalization, such that they are not interested in spending money on local food or products, but they would like to buy mass-produced goods more than goods from community enterprises. This issue has led to the shutting down of many community enterprises.

As we mentioned, enterprises experience a variety of management problems depending on the business environment and the situation during the research. Therefore, this paper studied problems and threats to the management of community enterprises, to find out the guidelines for the management of community enterprises. As well, this paper will provide some ideas for entrepreneurs and policymakers who are involved in community enterprises, allowing them to find out how to manage enterprises and solve problems. We also hope that our findings will serve as guidelines for management of community enterprises to achieve sustainability.

\section{Problems in and Threats to the Management of Community Enterprises}

According to the surveys and interviews that we conducted at community enterprises around the Songkhla Lake basin, regarding problems in and threats to the management of community enterprises, the research results are as follows:

\subsection{Marketing Problems Are a Major Problem that Most Community Enterprises Deal with}

Community enterprises are mostly established by local people who often lack knowledge on management and marketing plans. They normally run their businesses according to local wisdom; that is, they often think about a product selling plan after production is finished, which leads to difficulty in selling products in the market. To handle marketing and management principles, producers first have to survey the market demand before running the manufacturing process. They have to know what product the market needs, the product price, the target group, and other factors, and later apply these survey results to the products and services to meet consumer or market demand.

The next problem involves distribution channels and market expansion. This study found that community enterprises did not have many channels for product distribution. Their selling relies on trade exhibitions sponsored by the government and their own shops located within the community. They do not have markets to distribute products, and they do not have any connection support to distribute the products. In addition, lack of foreign language skills (e.g., English, Malayu, etc.) is another obstacle in dealing with the international market. By interviewing a candy manufacturer, this study found that:

\section{"Our group did not know very much about the market plan. We are just a small group and only sell our product within the local market. If possible, we need assistance from [the] government to distribute our product to more markets."}

In addition, from some case studies in Nakhon Si Thammarat Province, we found one entrepreneur producing and selling women's handbags. This kind of handbag is called a Krajood bag (Krajood is Lepironia articulata). Notably, this entrepreneur has had no problems marketing the handbag. The business can sell out of its products because these products are sold to the highest market segment (Krajood bags are very expensive, have very good design, and their customers are rich people). However, the business cannot sell to international markets because they cannot speak or write English, and they lack knowledge of international marketing.

\subsection{Problems with Accounting and Finance}

The study found that many community enterprises did not have good accounting management systems, which means that they do not know their own actual production costs. Owners normally mingle their business money with their personal expenses. In the case of multi-product manufacturing or multi-registering of enterprise groups, they did not categorize their accounting clearly, which led to a mingling of funds, so the source of income could not be identified correctly.

Financial problems are also caused by a lack of investment funding to develop businesses. A group could ask a financial institute for a loan, but most enterprises are unable to get loans because the members of community enterprises have to serve as the guarantors for any loan to the community enterprises. Most members did not want to be guarantors for the community enterprises for several reasons. For instance, they did not want to be responsible for the enterprise's problems if the enterprise could not repay the loan; as well, in some cases, loaned money has been used for personal purposes, not for the enterprise's business. Another problem is lack of cash 
flow in an enterprise because community enterprises in rural areas operate through middlemen by extending credit to them. The enterprise gets paid when products are sold. This payment approach is based on trust, and it is popular in the general trade system in rural society, as indicated by a community enterprise:

"Accounting seems like a major problem for a community enterprise because villagers do not have knowledge of that. The training is difficult to do because this knowledge is too difficult for rural people, and they also play many roles at the same time, such as being housewives to take care of the family. This may present limitations for learning new things."

\subsection{Problems with Production}

Some production processes require skilled labor, but the development of labor skills is still limited, which might affect the quality of a product. Another problem is production cost. Many community enterprises do not produce goods using raw materials from local resources, which might cause a product cost problem. Some manufacturers use local raw materials, but they also encounter material shortages due to the over-use of natural raw materials. Moreover, the 300-Baht minimum wage policy also directly affects the production mode of community enterprises.

Another problem is the development of quality in the production process, such as in enterprises that produce food and beverages. These businesses must develop the quality of production to meet the standards of the Food and Drug Administration (FDA) or earn a local product certificate. Many enterprises have been unable to develop their own standards, and this might affect the confidence of consumers.

\subsection{Problems with the Use of Information Technology}

This study found that many enterprises do not use information technology in their operations, such as creating a website to communicate and engage in public relations in the market or using an accounting computer program to help them run the organization's accounting system. Some enterprises have been encouraged to use accounting software, but they normally use their own approach to manage the accounting, as indicated by an interviewee:

"We would like to present our product through a website, but it is difficult to do that because our group has only housewives. We cannot do that. Someone told me to hire a specialist, but there no man to keep track of the work"

\subsection{Problems with Product Design}

Product design is a factor that appeals to the consumer in terms of packaging and products. However, community enterprises in the Songkhla Lake basin admitted that their product design and packaging processes were not good enough. Although some enterprises could get support from government agencies (e.g., universities) to design their packaging, they still could not design the package as they wished due to the high cost of product design. Therefore, enterprises had to develop products or packaging designs on their own, using local materials that can be obtained easily; or, they had to import low-cost materials made in a factory. In addition, it was found that some enterprises that had good product or packaging designs and had already accessed the market very well often imitated the product design of other manufacturers by making the same product but selling it at a cheaper price. The Cream Nests manufacturer stated that:

"A client has ever told us that the package is not beautiful. Why did we not hire a specialist to design something different? We have limitations in this. We had already hired a specialist to design it, but the specialist also received jobs from other suppliers at the same time. Every design then looked familiar. This is our problem."

\subsection{Problems Involving Production Costs}

The study found that most production in this area is done by hand, so the working skills of the members are very important. Machine production is still limited. Most of the production costs are associated with the labor required to produce the goods. This causes higher prices in the market compared with the same product as produced by machine. If the entrepreneurs do not plan the product position or product design well, it is typically difficult for them to compete with other competitors.

"Weaving is quite rare since the Kuan Kreng swamp forest caught fire two times. Our weaving work has also got a problem with the production process, [along with] a raw materials shortage, and increased competition. The products made from plastic are increasing in the market as well, and the selling of hand-made products is more difficult." (a group of 


\section{agricultural housewives)}

\section{Management Guidelines for Community Enterprises}

To study the management guidelines of community enterprises around the Songkhla Lake basin, the researchers invited nine stakeholders, including officers from the District Agriculture Office and related government agencies, community entrepreneurs, and enterprise management specialists to discuss guidelines for the management of community enterprises, as detailed below:

\subsection{Management Guidelines for Marketing}

The study found that marketing is a major problem for community enterprises. Thus, entrepreneurs have to change their production mode by applying a suitable marketing approach in the production process. Entrepreneurs have to survey the market demand before starting the production process. The survey revealed several questions that entrepreneurs need to ask, such as what product the market needs, the target group, market distribution, and more.

Government agencies, especially the Office of Provincial Agriculture, should play greater roles in marketing by integrating with local administrative organizations such as the Provincial Administrative Organization to provide a permanent provincial exhibition venue for community enterprises. They should allow the enterprises to put their products on shelves without charge. The government also should play a greater role as a coordinator between community enterprises. Regarding marketing opportunities, considering strengths, weaknesses, opportunities, and threats with regard to marketing capability, we found that local strengths are the raw materials advantage and the leadership of headman. The weaknesses are the lack of modern equipment and lack of market share. Opportunities include the popular trend toward making products with natural materials, as well as the few competitors in this field. The obstacles are the low rate of savings, lack of certification from the relevant authorities, and low incomes.

\subsection{Management Guidelines for Accounting and Financial Systems}

The study found that, although most community enterprises participated in a training course on accounting, most are still use an old system to run the process. This causes the entrepreneurs not to know the actual cost of production. Thus, the government should issue regulations regarding the accounting of community enterprises and always monitor the accounts of community enterprises to ensure that these businesses can do their accounts and manage their finances correctly.

\subsection{Management Guidelines for Product Design}

Government agencies, especially the Office of Provincial Agriculture, should act as the coordinator between community enterprises and academic institutes to assist the local enterprises in designing products and packaging without costs. At the same time, the academic institutions can apply these product designs as case studies for student learning. Assistance from government agencies will definitely help community enterprises to develop their abilities in terms of product design as well.

\subsection{Management Guidelines for Production Management}

Government agencies should support community enterprises in using raw materials that are easily found in the local area of production, and government agencies should also provide local citizens with an understanding of the conservation of the natural resources that are used as raw materials in production. Skill development should be provided to members of community enterprises before they start the work. In addition, governments should support community enterprises in developing product quality by providing knowledge and understanding of various factors. Government agencies such as the Provincial Agricultural Promoting Office will be the primary host to support community enterprises in their area.

\subsection{Skill Development in Foreign Languages}

The lack of foreign language knowledge is a major obstacle in the development of community enterprises. Government agencies should encourage local community enterprises to develop employees' foreign language skills by providing motivation for learning, providing training courses in foreign languages, coordinating with academic institutions to teach entrepreneurs, and other steps.

\subsection{Reducing Production Costs}

This step is the heart of production and services for commercial purposes. Thus, entrepreneurs have to focus on the use of local raw materials in production to reduce production costs. In addition, a problem that is normally found in hand-made production enterprises is the labor cost. To solve this problem, community entrepreneurs 
have to change the payment mode from daily payments to laborers to pay-per-piece.

\subsection{Management Guidelines for Information Technology}

Government agencies should focus on information technology issues, such as the use of information technology for marketing, product advertising, and promotion through online media such as the websites of government agencies or the businesses' own websites. The government should encourage community enterprises to develop their own abilities in this area by providing training courses on information technology, or creating instant Web pages free of cost to community enterprises.

\section{Conclusion and Discussion}

Government agencies are a key factor in encouraging the development of community enterprises. Agencies such as ministries, departments, or local administrative organizations have to collaborate in order to work through integrated coordination; that is, they have to work and exchange information together. Moreover, community enterprises will have to develop themselves by learning knowledge management for their organizations. Wasko and Faraj (2000) explained that knowledge management is a critical factor in developing an organization. Knowledge management is knowledge discovery, exchange, transfer, and acquisition from specialists. The development of a community enterprise as a learning organization is a way to help the organization achieve sustainability.

Production costs, especially labor and raw materials costs, are important issues that affect product price in the market. Entrepreneurs must find suitable approaches to managing problems, such as changing the payment mode from daily payment to pay-per-piece, or hiring contractors to work. Yang and Huang (2000) stated that better business management, such as reducing production costs, will result in improved management performance and better-quality products and services.

To solve marketing problems, community enterprises should not only manufacture products under their own brands, but also become subcontractors for large- or medium-sized industrial factories, for example, subcontracting to sew textiles or make shoes, and getting paid by the employer through pay-per-piece payments. Promsaka Na Sakolnakorn (2011) stated that community enterprises that enter the subcontracting sector will achieve a better economic status. This affects social issues, as people in a community will have work to do in their local area. As such, they will not need to migrate to work in other areas, such as Bangkok. Families get a chance to live together, and have more time to take care of their members.

Financial and accounting management has a critical effect on the survival of an enterprise. Financial problems are becoming major problems, and many enterprises are unable to avoid them. These problems are found across several issues, such as fundraising or cash flow. Certain elements of these problems derive from lack of financial management within the organization, or a suitable policy or plan to regulate the use of money in the organization. Promsaka Na Sakolnakorn et al. (2009) stated that entrepreneurs have to establish a financial management policy in their business plan and use financial resources to provide the greatest efficiency for the business. In addition, entrepreneurs have to know the principles of financial management and accounting management. Entrepreneurs who lack financial and accounting knowledge should ask for suggestions from government agencies to develop their own community enterprises.

In summary, government agencies are key organization in developing community enterprises. Community enterprises are established by people in a rural society. The government has continuously developed policies supporting community enterprises. However, the obstacle to management by the government is the integration of work among different agencies of the government.

\section{Policy Recommendations}

1) Knowledge of community enterprise management should be generated, for example, knowledge of accounting, production technology, product design, branding, and marketing management. Local academic institutes should play a role in closely practicing and monitoring the management of enterprises.

2) Networks should be established, especially among enterprises that run the same types of business, to help these enterprises exchange knowledge with one another through field study.

3) Reducing the process of dealing with government agencies is necessary, for example, requests to register community enterprises, requests for certificates from the Food and Drug Administration (FDA), and other requests for which community enterprises need support from government agencies.

4) A government agency should assess the status of community enterprises every year to encourage the enterprises to conduct business more adeptly and to help the enterprises in solving problems such as budget 
issues, knowledge management issues, or investment funding issues by providing support for loans with low interest rates and reasonable terms.

\section{Acknowledgements}

This study was financially supported by the Faculty of Liberal Arts, Prince of Songkla University, for fiscal year 2011.

\section{References}

Adonisi, M., \& Wyk, R. van. (2012). The influence of market orientation, flexibility and job satisfaction on corporate entrepreneurship. International Business \& Economics Research Journal, 11(5), 477-486.

Bailey, N. (2012). The role, organisation and contribution of community enterprise to urban regeneration policy in the UK. Progress in Planning, 77(1), 1-35. http://dx.doi.org/10.1016/j.progress.2011.11.001

Basco, R., \& Rodriguez, M. J. P. (2011). Ideal types of family business management: Horizontal fit between family and business decisions and the relationship with family business performance. Journal of Family Business Strategy, 2(3), 151-165. http://dx.doi.org/10.1016/j.jfbs.2011.07.004

Development Trusts Association. (2000). Annual report. London: Development Trusts Association.

Gorman, G. G., Rosa, P. A., \& Faseruk, A. (2005). Institutional leading to knowledge-based businesses. Journal of Business Venturing, 20(6), 793-819. http://dx.doi.org/10.1016/j.jbusvent.2004.04.002

Jariyapong, M., Roongtawanreongsri, S., \& Kheowvongsri, P. (2010). Values of local vegetable and a current situation of utilization at Ban Wanglung, Tonhong sub-district, Phrom Khiri district, Nakhon Si Thammarat province. Songklanakarin Journal of Social Science and Humanities, 16(1), 93-113.

Kongmanila, X., \& Takahashi, Y. (2009). Determinants of subcontracting in Lao garment industry. Contemporary Management Research, 5(3), 273-286.

Lee, J. S., \& Hsin, P. L. (2004). Employee training and human capital in Taiwan. Journal of World Business, 39(4), 362-376. http://dx.doi.org/10.1016/j.jwb.2004.08.004

Nambure, N. (2012). Development of accounting system for community enterprise in three southern provinces of Thailand. SKRU Academic Journal, 5(1), 14-25.

Netemeyer, R. G., \& Maxham, J. G., III. (2007). Employee versus supervisor rating of performance in the retail customer service sector: Differences in predictive validity for customer outcomes. Journal of Retailing, 83(1), 131-145. http://dx.doi.org/10.1016/j.jretai.2006.10.009

Petprasert, N., \& Wongkul, P. (2002). Community enterprises: Economic mechanism for grass root. Bangkok: Edison Press Production.

Pongpit, S. (2005). Thinking villages: A vision for development. Bangkok: Jaroenwit Publishing.

Promsaka Na Sakolnakorn, T. (2011). Economic and social development by management using outsourcing and subcontracting strategy. The International Journal of Environmental, Cultural, Economic \& Social Sustainability, 7(5), 273-286.

Promsaka Na Sakolnakorn, T. (2011). The good aspects of managing an organization with an outsourcing and subcontracting strategy. International Journal of Management and Information Systems, 15(3), 11-18.

Promsaka Na Sakolnakorn, T., \& Sungkharat, U. (2013). Development guidelines for small and micro community enterprises in Songkhla lake basin. Songkhla: Faculty of Liberal Arts, Prince of Songkla University.

Promsaka Na Sakolnakorn, T., Aim-Im-Tham, S., \& Khamanarong S. (2009). Management strategy for administration of textile industries in developing country: Case study Thailand. Journal of Business Case Studies, 5(3), 37-44.

Promsaka Na Sakolnakorn, T., Khamanarong, S., Khamanarong, K., Imtavil, V., \& Overton, J. (2010). Industry outsourcing and regional development in northeast Thailand. Asia Pacific Viewpoint, 51(1), 106-112. http://dx.doi.org/10.1111/j.1467-8373.2010.01416.x

Purateera, T., Khmanarong, S., Phanarata, A., \& Khamanarong, K. (2009). Influence factors affecting management of small enterprises in Northeast Thailand. International Business \& Economic Research Journal, 8(2), 41-46.

Ratanachai, C., \& Sutiwipakorn, W. (2006). Lessons on master plan development and stakeholder engagement form the Songkhla Lake Basin case. Retrieved May 2, 2013, from http://wldb.ilec.or.jp/ ILBMT 
rainingMaterials/resources/Songkhla.pdf

Runglertkrengkrai, S., Sirirat, J., Somboonkul, Y., Chulirachaneekorn, S., Chulirachaneekorn, S., Samansri, J., \& Ruangsong, R. (1999). The characteristics and training needs for small and medium entrepreneurs in the southern Thailand. Songklanakarin Journal of Social Science and Humanities, 5(3), 233-243.

Saengthong, P. (2010). The guideline for marketing improvement of the community enterprises: The case study of Mae Ban Kasettakorn's Kohyor hand-woven fabric, Tambon Kohyor, Mueang district, Songkhla province. SKRU Academic Journal, 3(1), 1-6.

Seyoum, B. (2007). Trade liberalization and patterns of strategic adjustment in the US textiles and clothing industry. International Business Review, 16(1), 109-135. http://dx.doi.org/10.1016/j.ibusrev.2006.12.003

Suantan, A., Darnsawasdi, R., \& Kamphoo, P. (2008). Diversity of wildlife and its economic utilization in Khao Hua Chang community forest, Tamot subdistrict, Tamot district, Phatthalung province. Songklanakarin Journal of Social Science and Humanities, 14(1), 85-104.

Swenson, D. L. (2005). Overseas assembly and country sourcing choices. Journal of International Economics, 66(1), 107-130. http://dx.doi.org/10.1016/j.jinteco.2004.07.005

Wasko, M., \& Faraj, S. (2000). It is what one does: Why people participate and help others in electronic communities of practice. Journal of Strategic Information Systems, 9(2-3), 155-173. http://dx.doi.org/10.1016/S0963-8687(00)00045-7

Yang, C., \& Huang, J. B. (2000). A decision model for IS outsourcing. International Journal of Information Management, 20(3), 225-239. http://dx.doi.org/10.1016/S0268-4012(00)00007-4

Yim, C. K., Chan, K. W., \& Hung, K. (2007). Multiple reference effects in service evaluations: Role of alternative attractiveness and self-image congruity. Journal of Retailing, 83(1), 147-157. http://dx.doi.org/10.1016/j.jretai.2006.10.011

\section{Copyrights}

Copyright for this article is retained by the author(s), with first publication rights granted to the journal.

This is an open-access article distributed under the terms and conditions of the Creative Commons Attribution license (http://creativecommons.org/licenses/by/3.0/). 